NBSIR $75 \cdot 711$

\title{
Site Analysis and Field Instrumentation for an Apartment Application of a Total Energy Plant
}

John B. Coble and Paul R. Achenbach

National Bureau of Standards

Department of Commerce

Washington, D.C. 20234

May 1975

Final Report

Prepared for

U.S. Department of Housing and Urban Development

Washington, D. C. 20410 


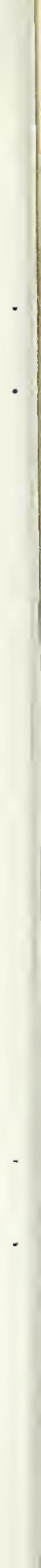


NBSIR 75-711

\section{SITE ANALYSIS AND FIELD INSTRUMENTATION FOR AN APARTMENT APPLICATION OF A TOTAL ENERGY PLANT}

John B. Coble and Paul R. Achenbach

National Bureau of Standards

Department of Commerce

Washington, D.C. 20234

May 1975

Final Report

Prepared for

U.S. Department of Housing and Urban Development

Washington, D.C. 20410

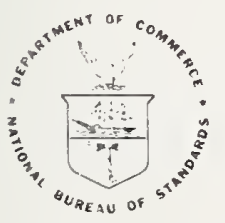

U.S. DEPARTMENT OF COMMERCE, Rogers C.B. Morton, Secretary NATIONAL BUREAU OF STANDARDS, Richard W. Roberts. Director 
TABLE OF CONTENTS

SITE ANALYSIS FOR THE APPLICATION OF 1 (First section) TOTAI ENERGY SYSTEMS TO HOUSING DEVELOPMENTS

DESCRIPTION OF EQUIPMENT AND INSTRUMENTATION 1 (Second section) FOR A FTELD STUDY OF A TOTA ENERGY SYSTEM IN AN APARTMENT DEVELOPMENT 
SITE ANALYSIS FOR THE APPLICATION OF

TOTAL ENERGY SYSTEMS TO HOUSING DEVELOPMENTS

By

P. R. Achenbach and J. B. Coble

National Bureau of Standards

Washington, D. C. 20234

presented at

7 th Intersociety Energy Conversion Engineering Conference San Diego, California September 25-29, 1972 


\section{SITE ANALYSIS FOR THE APPLICATION OF TOTAL ENERGY SYSTEMS TO HOUS DNC DEVELOPMENTS}

\section{By}

Paul R. Achenbach and John B. Coble

\section{Introduction}

Concurrent with the natlonal effort to accelerate housing constructun in the United States, there has been much concern abuut the continued

10 avallabllity of some forms of energy used in housing and the effects of energy use on environmental quality. Low reserves in electric generating capactity and natural gas exlst in many highly populated areas of the country and the Importation of oll is increasing rather sharply to meet growing requirements.

15

These dnd other factors have caused the Department of Housing and Urban Development to ut 11 ize a part of their Operation BREAKTHROUGH housing program for a fleld investigation of total energy systems as a means for saving tilel and reduclng pollution and for making the electrical services independent of the local utility system. Initiated in mid-1970, the

20 design and construction of about 2800 dwelling units ${ }^{\star}$ on eleven sites in the country to encourage industrlallzation and innovation in the homebullding process. The National Bureau of Standards wes requested to examine the feasibllity of ut $11121 \mathrm{ng}$ total energy systems for one or more of these eleven sites to develop reliable data on thermal efficlency, dally t ive of the kind of building in which it is incorporated. 
and seasonal load paterns, rellablitty and stabllity of the utility services, the level of nolse and pollution control, the antenance and repair requirements, and the owning and operating cost. The number of sites used for the BREAKTHROUGH program was later decreased to nine.

5 This program is a part of a broader program on utilitles research being carrled out by the Utilttes Technology Division in the Office of the Assistant Secretary for Research and Technology of HUD. 


\subsection{Total Energy System Characterist1cs}

\section{?.1 Derintion}

A total energy system is characterized by four principal concepts:

a) The electric energy for the development 18 generated on site.

b) Waste heat from the electric generation equipment is recovered and used on site for hearing, coollng, or process functions.

c) The plant is located within the confines of the site being served.

d) It serves a single buliding or a comercial, Industrial, or residential ste that 18 not traversed by public thoroughfares.

The constraint on distribution of electric energy across public thoroughfares is a part of the franchise agreements accorded to the electric ut 11 ties .

\section{?.2 System Loads}

The principal loads on a total eneray system in a residential application are: electricity for ligh:ing, motors, and appilances; space heating; space cooling; and domestic hot water heating. If there is communty development assoclated with the site there will be other types of loads on the system that are characteristlc of the particular facllitles. There are dally, weekly, and seasonal cycles to the four principal componerits of the load in a residential application of a total energo system. Under ravorable conditions the electric energo requirements and the possible uses of the waste heat of a given application are so proportioned 
that the total amount of energy utilized by the total energy system 18 significantly less than would occur if electric energy were taken from a central ut1l1ty system at a ut $1112 \mathrm{ation}$ efflciency of about 30 perceat and the other energy requirements were supplied by fuel-burning equipment at the site. To the extent that this favorable balance of loads occurs, there $1 \mathrm{~s}$ good potential for lowering fuel usage and, In come cases, overall annual cost for energy by ut111zating a total energy system. Some capability for auxll1ary heating and for dumping unneeded heat 18 usually provided in a total energy gystem. Certain types of loads from comercial or comuntty facilities help to improve the overall balance between electrical dewand and the demands for waste heat.

Corollary benef1ts sometimes clalmed for total energy systems are: greater rellability in electric service, conservation of energy resources, and overall reduction in the discharge of heat and combustion products Into the environment.

\subsection{Equ1pment Comb1nat1ons}

Total energy systems could be designed to utllize a varlety of fuels; however, nearly all systems now in operation use natural gas, diesel fuel, or a combination of gas and oll.

A total energy system cas be made up of a wide varlety of mechanical equipment assembled in various combinations. Internal or extermal combustion engines or turbines can be used for driving electric generators and air conditioning compressors. The latter equipment can be of either the reciprocating, rotary, or centringal type. Absorption water chillers can be used alone or in combination with compression water chillers to provide air conditioning. Space heating can be accomplished by electric 
resistance heating or by circulating steam or hot water. Space heating and cooling can be provided by heat pumps. Domest1c water heating can be done by ut111zing waste heat and a heat exchanger, or by using gas, o11, or electrlc energy directly as the heating source. Not all of these equipment cholces lend themselves to an efficlent ut 1112 ation of waste heat or to attalning an optimum relation between electric energy requirements and waste heat requirements in a total energy system when considering the dally and seasonal load varletions. Nevertheless, a number of combinations should be evaluated in engineering and economic terms for 10 any given installation.

2.4 Current Applicat1ons 1/* $^{\text {* }}$

There are approximately 550 total energy plants in operation in the Unlted States at the present time ranglng in size from 0.2 megawatts to more than 20 megawats. Installations of total energy planto began about 1958 and reached a peak, In numbers of new plants installed, in 1967. However, the total electrical capacity of new plants installed annually has continued to rise. Total energy systems at present account for approximately 0.2 to $0.3 \%$ of the electrical generating capac1ty of the Untited States.

About $70 \%$ of the plants utillze reclprocating gas englnes and an additional $15 \%$ employ gas-fired turblnes as the prime wovers. The remalnder ut $111 z e$ diesel englnes, steam turblnes, or dual-fuel engines employlng natural gas and fuel 01l. A large majorlty of the total energy systems serve 1ndustrial and comerclal applications, with only about $5 \%$ serving residential applications. At this time over $60 \%$ of existing 25 plants have less than I megawat generating capac1ty, but the plants installed in the last few years have averaged over 5 megawate in capacity. 


\begin{abstract}
A signiflcant number $2 /$ of total energy plants have been deactivated in recent years, with a high percentage of these having a capacity of 0.5 megawat or less.
\end{abstract}

\title{
3.0 Site Ranking Parameters
}

Many factors have a bearing on the sultabllity of a housing development for the use of a total energy system. For the BREAKTHROUGH housing sites, these parameters were separated into three groups having primarily technical, adminfstrative, and economic significance, respectively.

The parameters of a technical nature were: the number of dwelling untes and their density and arrangement on the site; the sumer and winter degrer days and the design temperatures at the site; and the method of construction and assembly of the housing systems as related to the ease in bringing the ut1l1t1es into the houses. The adminlstrative considerations were: the number of different housing systems to be built on the s1te; the current and anticlpated level of electric capacity reserves applicable to the site; the amount and kind of communty development to be provided on the site; the time schedule for beginning of construction; and the knowledge and interest of the site planner and site developer in a pilot installation of a total energy system. The flnancial parmeters were: the relative cost of purchased electrical, gas and oil energy at the site; the first cost difference between the total energy system and the conventional system which it might replace; and the cost of maintenance and repair.

Information was collectod on the relative magnitude or importance of a.1 of these parameters for the $s: x$ BREAKTHROUGH sites that appeared to be better sulted to total ener systems; namely, Jersey City, Memphis, St. Louls, Macon, Sacramento, and Indianapol1s. The other f1ve s1tes at 
Wilmington, Houston, Kalamazoo, Seattle (2 eltes) were eliminated because of the smaller number and lower density of the dwelling untts on these Bltes.

\subsection{Number and Density of Dwe $111 \mathrm{ng}$ Units}

Several housing system producers are constructing groups of dwelling units on each of the BREAKTHROUGH sites. The dwelling units on each site are distributed smong four basic types of construction: mult1-family h1gh-r1se(MFHR); mult1-fam1ly low-rlse (MFLR); single-family attached (SFA); and single-family detached (SFD). The $81 x$ sites chosen for de-

10 talled consideration as experimental sites for total energy systems were those with the higher numbers of dwelling unlts, since a total energy system has usus 1ly been found to be uneconomical for developments of less than about 200 dwelling units and for low density housing.

Table 1 shows the size of the BREAKTHROUGH sites at Jersey City,

15 Macon, Memph18, Indienapol18, St. Lou18, and Sacramento; the total number (1) dwelling unlts being bullt, and the percentage of each of the several types of constuction. The density of the housing ranges from a maximum of about 77 dwelling units per acre et Jersey City to a minimum of about 6 dwelling units per acre at Macon. For the s1x sites, the 20) dwelling unlts in high-rlse bulldings range from 12 to 98 percent of the total. There are no single-family detached dwelling units on the three smaller sites. Since a total energy system delivers energy-related services from a central source, the unit cost of distribution 18 approximately proportional to the slze of the site and Inversely to the density of the disling units on the site. 
Table 1. Site S1ze and Drelling Unit Dietribution on Six BREAKTHROUGH Sites

\begin{tabular}{|c|c|c|c|c|c|c|c|}
\hline & & & & Dwe 1 & $\ln 15$ I & \%. 0 & tal \\
\hline 5 & Site & $\begin{array}{l}\text { Area } \\
\text { Acres }\end{array}$ & $\begin{array}{l}\text { Total } \\
\text { Units } \\
\end{array}$ & MFHR & MFLR & SFA & $\underline{S F D}$ \\
\hline & Jersey City & 6.35 & 488 & 98 & 2 & -- & $-\infty$ \\
\hline & Macon & 50.0 & 287 & 20 & 23 & 52 & 5 \\
\hline & Memph1s & 16.0 & 374 & 55 & 27 & 16 & \\
\hline & Indlanapolis & 42.9 & 287 & 12 & 5 & 48 & 35 \\
\hline 10 & Sacramento & 33.0 & 407 & 28 & 24 & 42 & 6 \\
\hline & St. Louls & 15.5 & 464 & 44 & 10 & 46 & $=-\infty$ \\
\hline
\end{tabular}

\subsection{Climat1c Factors}

Since the economy of a tolal energy system is dependent on making

15 use of the waste heat from the engine-generator equipwent used for electrlc power production, it is important that there be a reasonably steady demand for the waste heat throughout the year. Thus a total energy system would not usually be economical in a residential application unless some absorption alr-conditioning is used, because the heating of domestic

20 hot water may utilize leas than one-third of the waste heat avellable durlng the four or flve warmest months of the year.

The climatic factors that have a direct bearing on the economy and capacity of a total energy system for a residential development are the summer and winter outdoor design temperatures and the degree-days of

25 heating and cooling for each site. The algnificant weather data for the $61 x$ sites under consideration are shown in Table 2. 
Table 2. Climatic Date for Six BREAKTHROUGH Sites

\begin{tabular}{|c|c|c|c|c|c|c|}
\hline \multirow{3}{*}{5} & \multirow{3}{*}{$\begin{array}{l}\text { S1te } \\
\text { Jersey City }\end{array}$} & \multicolumn{2}{|c|}{ Winter } & \multicolumn{3}{|c|}{ Sumer } \\
\hline & & \multirow{2}{*}{$\begin{array}{l}\begin{array}{c}\text { Degree- } \\
\text { deys }\end{array} \text { S/ } \\
4902\end{array}$} & \multirow{2}{*}{$\begin{array}{l}\text { Out door }{ }^{\mathrm{b}} \\
\text { Des1 gn } \\
\text { Temp., }{ }^{\circ} \mathrm{F}^{3}{ }^{3} / \\
15\end{array}$} & \multirow{2}{*}{$\begin{array}{l}\text { Hours at } \\
67^{\circ} \mathrm{F} \text { WB } \\
\text { or above } 4 / \\
1290\end{array}$} & \multicolumn{2}{|c|}{$\begin{array}{l}\text { Outdoor } \\
\text { Des1gn } \\
\text { Temp. of } 3\end{array}$} \\
\hline & & & & & $\frac{D B}{89}$ & $\frac{W B}{76}$ \\
\hline & Macon & 1797 & 27 & 3069 & 96 & 79 \\
\hline & Memphis & 3006 & 21 & 2631 & 96 & 79 \\
\hline 10 & Ind lanapolis & 5611 & 4 & 1462 & 91 & 77 \\
\hline & St. Louls & 4469 & 11 & 1866 & 94 & 78 \\
\hline & Sacramento & 2822 & 32 & 351 & 97 & 70 \\
\hline
\end{tabular}

${ }^{a}$ Besed on an indoor temperature of $65^{\circ} \mathrm{F}$.

based on $971 / 2 \%$ of winter hours being at, or above this temperature.

Based on $21 / 2 \%$ of sumer hours being at or above these temp.

15

In cooler climates the size of the supplemental boller will likely be decermined by the maximum winter heating load, whereas in warmer

20 climates the size of the supplemental boller may be determined by the maximum cooling load, If absorption cooling is used. In warm and humid cllmates the number of hours during the sumer when the outdoor wet-bulb temperature 18 at or above $67^{\circ} \mathrm{F}$ 1s a good indicator of the amount of time that alr conditioning will be required, but in hot and dry climates 25 a dry-bulb temperature criterion 1 s more rellable. 


\section{3 Analys 1s of Energy Usage \\ 3.3.1 Space Heating and Cooling Loads}

Calculations were made of the expected loads for space heating and cooling, domestlc water heating, and miscellaneous electrical uses at

each of the $91 \times$ BREAKTHROUCH sites. Th1s information was needed to determine the approximate slze of the total energy plants, the applicable energy rate schedules, the avallab1l1ty of approprlate system components, the differential in first costs, and the amount of space needed for the plant on the site. At the time of these calculations, the materials of construction, the slze of each type of dwelling unit, and the number of each alze of dwelling untt were known.

The gross monthly energy requirement for space heating and cooling and the maximum monthly energy demand rate were calculated for each alte using the following procedures:

Monthly Heating Energy Requirement, Btu -

Monthly Heating Degree-Days $x\left[\left(H_{1} \times A_{1}\right)\right.$

$H L_{1}$ is the heat transmission for a type 1 bullding in Btu/ (ft ${ }^{2}$

floor area) (degree-day). This quantity was calculated by a computer program using a transfer function technique to deteralne the dynamic reaponse

of the bullding to the total environment (temperature, wind, solar radiation, orlentation, Internal loads, etc.) The quantlty HL, was determined for five different types of bulldings; namely, mult1-famlly high-rlse, mult1family low-rise, single-family attached, single-family detached, and nonresidential. The non-residential classiflcation included comercial bulldings, school bulldings, plant and public speces. 
$\Lambda_{1}$ is the total floor area of each type of bullding in the development, $f t^{2}$.

Monthly Cooling Energy Requirement, Btu -

$$
\text { Monthly Cooling Degree-Days } \times\left[\left(C l_{1} \times A_{1}\right)\right.
$$

$5 \mathrm{CL}_{1}$ was determined for each type of bullding ueing the computer technique that was used for calculat $\ln _{8} \mathrm{HL}_{1}$.

Maximus Monthly Heating Load Demand, Btu/hr =

$$
\left.\frac{\left(75-T_{m 1 n}\right)}{(75-11}\right) \quad\left[\quad\left(W_{1} \times A_{1}\right)\right.
$$

$10 \quad H D_{1}$ is the maximum heating demend determined for the different bullding types in the Jersey City site for ateady outdoor temperature of $11^{\circ} \mathrm{F}$, which 18 the $99 \%$ design temperature for Newark, N.J., expreseed in Btu/(hr) (ft $\left.{ }^{2}\right)$. The maximum monthly heating loed demand calculated by equation (3) and the maximum monthly cooling load demand calculated by equation (4) were 15 normalized on Jersey City because extensive calculations of the demands by the bulldings for the Jersey City site had been carried out.

$T_{m i n} 18$ the 30-year average of the minimum dally temperature for the month and the site belng considered.

The maxtmum monthly heating load demand was taken as zero, if equation

(3) ylelded a negative value.

Maximum Monthly Cooling Load Demand, Btu/hr =

$$
\frac{\left(T_{\max }-75\right)}{(91-75)} \quad \sum\left(C D_{1} \times A_{1}\right)
$$

$C D_{1}$ was calculated slmilarly to $\mathrm{HD}_{1}$ based on data for Jersey C1ty 25 bulldings and a maximum dally temperature of $91^{\circ} \mathrm{F}$. 
Imax is the maximum dally temperature (besed on a 30-year averege) for the month and ite being conidered.

The maximum monthly cooling losd demand wes taken se zero, if equation 4 resulted in a negntive value.

5

\subsubsection{Electric1ty and Domest 1c Hot Water Uease}

Published information $6,7,8,9 /$ on the usege of electricity for domest1c hot water and for miscellaneous purpoces in dueling units in the United States was used is the besis for estiating these energy requirements

10 it the varlous areakThrough stes. From these sources it was estimated that the monthly electrical usege per dwelling unit for miscelleneous purposes would be 702 kllowet hours and the dally ueage of hot water would average 41 gallons per day. These estates take into account the observed 6\% annual Increase in electrical use ince the data were collected.

15 The average hot water usage wa edjusted for the storage loses. Monthly varlations in electricity and dosectic hot water usege were adjusted to agree with observetlons shown in the published reporte referenced above. 


\subsubsection{Energy System Simulation}

The overall energy requirement for a given housing development is different for different types of energy ut 1 lizetion systems. Considered In this analysis were seven different systems; three were different types of total energy systems, two were all-electric systems, and two were conventional systems.

An all-absorption alr-conditioning system was assured for one of the total energy systems, engine-driven centrifugal compressors were assumed for a second, and varying combinations of absorption and englne-driven

10 compression alr conditioning were assumed for the third. Other components were identical. One all-electric system used resistence heaters for space heating and wotor-driven compreselon alr condltioning; the other llsed Individual atr-to-alr heet pumps in each dwelling untt for year-round space conditioning. The two conventional systems utllized electric

15 energy from the municipal system and fossil fuel for heating functions. One conventional syatem used all absorption alr conditioning and the other motor-driven compressors for a ir conditioning.

A computer program was prepared to calculate the monthly and annual cnergy usage for each of the seven energy systems described above for

20 the BREAKTHROUGH sties at Jersey City, Macon, Memphls, Indianapolls, Sacramento, and St. Louis. The equipment efficlencles and performance factors used in these computations were as follows: 


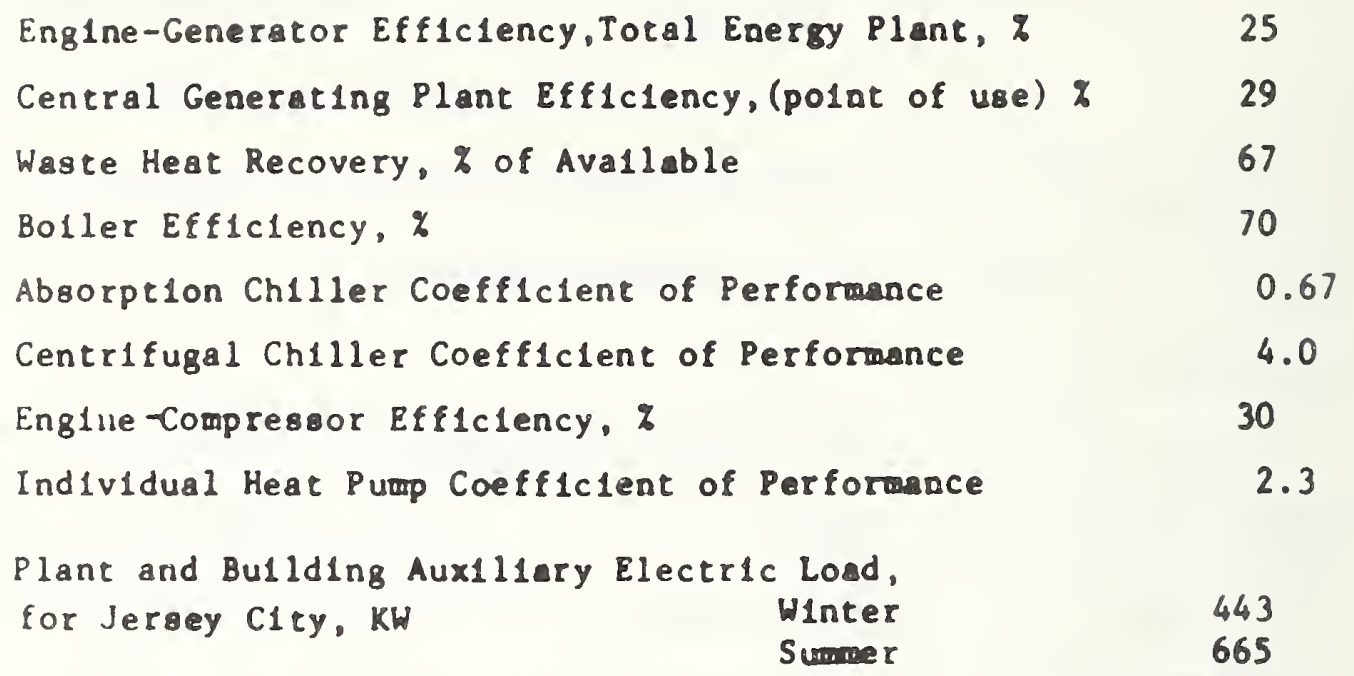

Table 3 shows the calculated energy requirements for the several different energy ut111zation systems. Four different combination of absorption and compression afr condttioning equipment were evaluated for the total energy concept, in addition to all-absorption and all-couprea sion alr-conditioning systems.

Table 3 shows that the total energy syetew using all-absorption alr condltioning had the lowest overall energy requirement at Jersey C1ty, whereas a combination of $40 \%$ absorption and $60 \%$ compression alr conditioning in a total energy plant was wost economical in energy use at four of the other sites. It 18 belleved that the electrical energy requirements for the commercial and school aress and the electrical auxil1aries (pumps, blowers, etc.) In the total energy plant ralsed the level of avallable wate heat at the Jersey Clty site sufficlently to satiofy a high percentage of the thermal energy requirement of the absorption alr conditioning system, thus making absorption cooling the best alternative at this alte. 
The most economical total energy plant aved from 28 to 40 percent of the energy required for a conventional system using absorption chlllers for alt condittoning at the several sites. It was assumed that electri(a) energy was purchased from the local electric utllity system in the 5 convent lonal plants. 


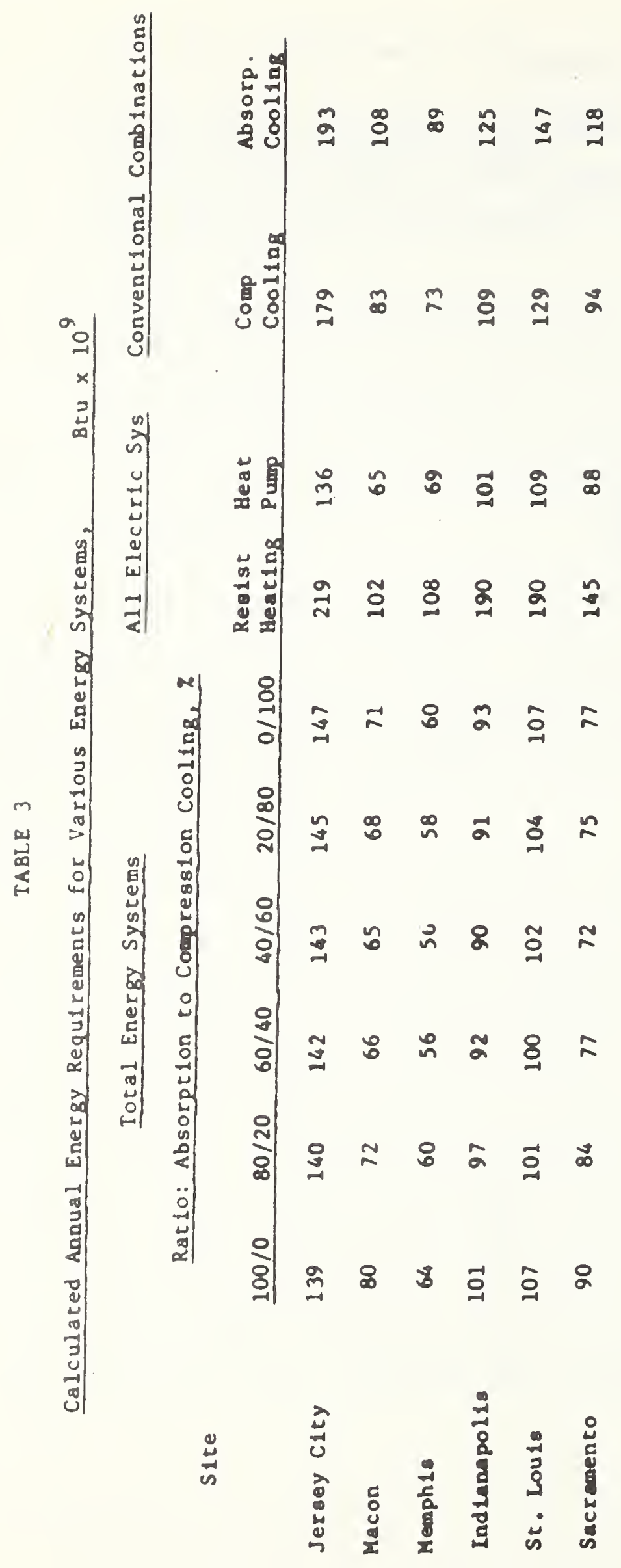




\subsection{Finergy Costs}

tinergy cost Information for the $61 \times$ BREAKTHROUGH sites was obtained from the latest published schedules for gas and electricity and from quotations of local fuel oll dealers, as of Apr11 1972. In each location the electric and gas ut 111 ties have establlshed several rate schedules which apply to different resident1al, comercial, and Industrial loads. For computing the monthly and annual energy costs at each site, those rate schedules wh1ch provided the lowest cost for energy and whlch were applicable to the particular ut111ty system under consideration were used. The rate information for 898,011 and electricity 1 s sumarlzed In Table 4. For each kind of energy, the costs cired include both the demand change and the energy consumption charges. For fuel o1l, the unlt cost is not dependent on the amount consumed when the fuel 18 delivered in bulk lots to the central ut1lity plant.

Separate electrical energy costs are shown in Table 4 for single metering of all energy used in the development and for Individual metering of the electrical energy used in each dwelling unit for three different energy systems: namely, heating and cooling with a heat pump In each dwelling, electrical resistance heating and a unttary alr conditloner in each dwelling, and a fuel-flred heating unit and unftary air conditioner in each bullding. The range of unit electrical energy costs shown in each block of Table 4 covers the variations in monthly use throughout the 12 months of the year.

The costs shown in Table 4 represent algniflcant increase in 25 comparison with those avallable in August, 1970, when the feas1b1lity study was flrot made. 011 prices have increased an average of about 


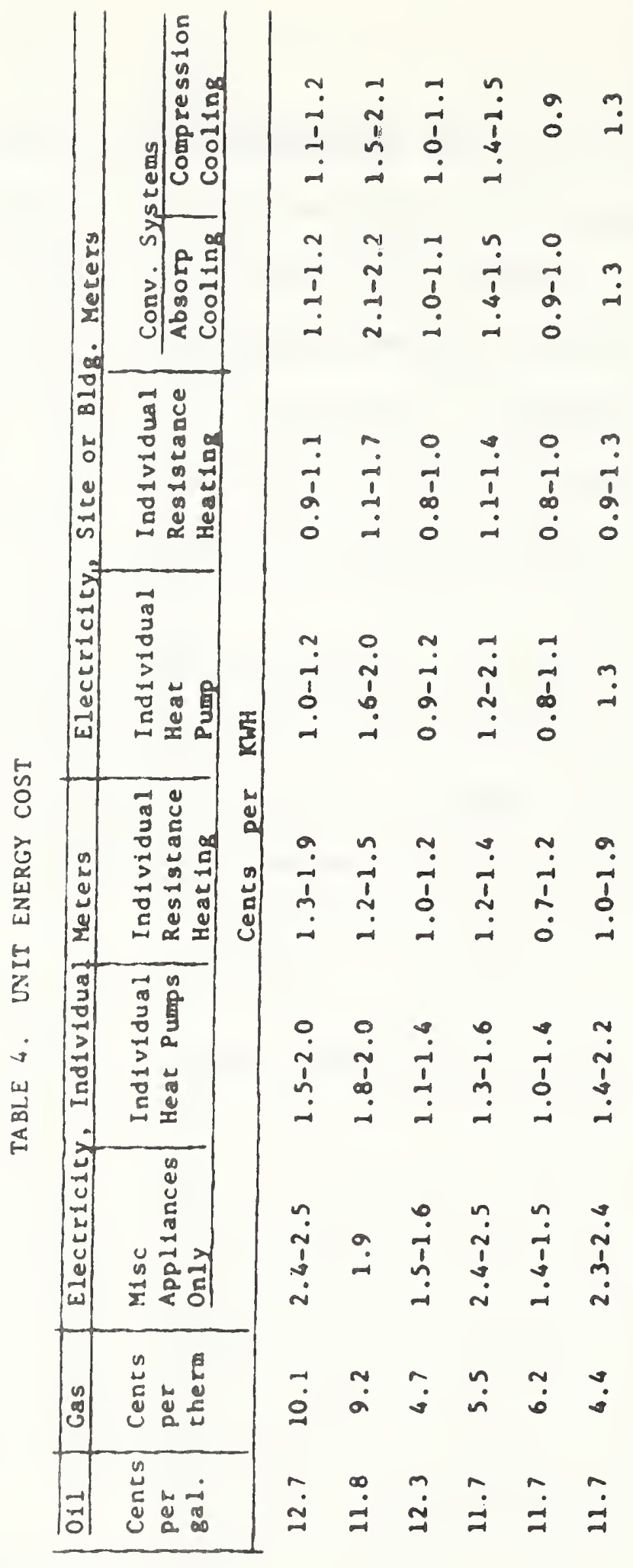

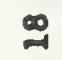

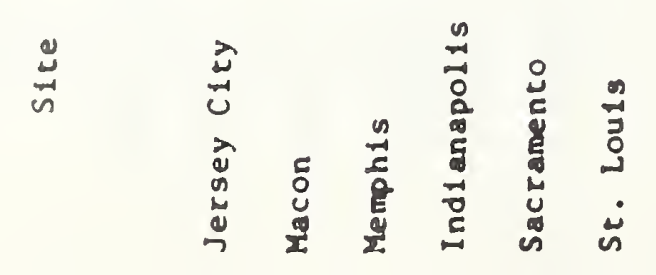


7 percent In the $31 x$ c1t1es, ranglng from no increase in Macon to $11 \%$ In St. Louls and Sacramento. The cost of gas has 1ncreased an average of 22\% in flve of the citles, not 1ncluding Macon, where the Increase has been $104 \%$ in two years. Th1s unusally large lncrease in Macon. 1s largely 5 due to the termination of a very favorable incentive-type schedule that was in effect when the previous informat1on was collected in August, 1970.

The cost of electricity has increased frow 30 to 40 percent at Jersey C1ty, Indlanapol1s, St. Lou1s, and Sacramento dur1ag the lest two

10 years for large loads exceeding one w1110n k1lowat-hours per noath. The Increases were even larger in Macon and Mempls, approximately $60 \%$ and 100\% respectively, for a studlar load range. The increases in lower load ranges are of the same order of mantude.

The annual energy requirements shown in Table 3 and the unt energy and fuel costs shown in Table 4 for the different types of service at the six sites were used to calculate annual energy costs for each of the different ut1lty oystems. These annual energy costs are shown In Table 5 for six different equlpment comblnations in a total energy plant and for both 011 and gas. For the all-electrlc syotem and the conventlonal systems using a combination of fosall fuel and purchased electric1ty $1 t$ was assumed that all of the electrical energy was wetered by one weter. Table 5 show that oll was the more economical fuel at Jersey City and Macon, and $\mathrm{gas}$ was more economical at the other four sites for both the total energy and conventlonal systems. The most economical total 25 energy system at each site saved frow 25 to 60 percent of the energy cost for the comparable conventional plant using motor-driven compreasioa coollag 
and from 30 to 59 percent of the energy cost for the comparable conventional plant using absorption cooling. The calculated cost saving at Jersey City wa: Ihro lowest of the six sites, because comerclally produced electricity 5 and oll are more competitively priced in Jersey C1ty than at the other stes.

\subsection{Owning and Operating Cost8}

Precise determination of typlcal ownlng and operating costs for ut lifty systems is difficult to develop at present because the costs of 10 machinery, materials, fuel, and labor are all changing rather rapidly. At any given tlme the costs of gas and electriclty are published, but new schedules are appearing at Irregular intervalo so future costs w111 change accordingly.

The flrst costs for the total energy system at Jersey City are summarlzed in Table 6. There 18 some uncertalnty in the flgure cited for 15 the cost of the bullding since 1 will house both the total energy system and the solld waste collection, compacting, and loading system. Half of the total bullding cost was allocated to the total energy system in Table 6.

The design and construction magement costs are relatively high 20

for the Jersey City installation for a number of reasons, including the following:

a) Coordination of the plans for at least four different bullding types,

b) Redesign of some of the bulldings and changes in housing system producers,

c) Incorporation of an Innovative wate disposal syated on the site,

d) Provision for installation of data collection equipment and for 
fleld experimentation on both the total energy system and the solid waste disposal system,

e) Provision of more atandby electric-generating equipment than typlcal and provision of some additional space for future Installation of Innovative components.

The cost data in Table 6 show that the Iavestment cost for the total energy system w111 be about $\$ 4,900$ per dwelling un1t, if the cost 18 pro-rated between the residentlal area and comerclal fac1litles in proportion to floor area. The overall investment cost for providing the on-site generating fac1l1ty 18 estimated at $\$ 720,000$ or $\$ 240$ per kflowatt of Installed capacity. Th1s flgure lacludes the purchese cost of the englne-generators and controls and pro-rated costs for system deslgn, equipment bullding, Installation costs, and construction management costs. Thls value of cost per kllowat of installed capac1ty can be used for est Imating flrst cost differences between a total energy system and a conventional central heating and cooling plant at the five other BRRAKTHROUCH sites under conalderation, since they are all almilar in size. Sufficlent data on the cost of maintenance and service costs for total energy systems are not avallable to clte a rellable average value. However, a limited number of publ1shed reports indlcate that contracts for malntenance and service of englne-generators, wth elther turblne or reciprocating englne drive, are in the range of 0.3 to 0.4 cent per kllowat hour of energy produced. The annul contract cost of malntenance and service for heating and cooling equipment is in the range from $\$ 20$ to $\$ 30$ per ton of 1notalled refrigeration capacity. These f1gures apply to plants in the size range needed for the BREARTHROUCH housing a1ter. 


\section{Table 6}

\section{Costs of Total Enercy System at Jersey C1ty, Rew Jersey}

Purchase Cost

Engine-Cenerators

Generator Controls

$\$ 315,000$

Cooling Towers

91,000

57,000

Central Equipment Bullding, Prorated

Construction, Total Energy Plant, Including purchase of heat1ng/coollng equipment

$1 ; 093,000$

Subtotal

$1,805,000$

Ut1lity Distribution System

367,000

Design and Masagement Costs

Total Energy System

Site Utilities

Central Equipment Bullding

Construction and Contract Management

Subtotal

125,000

141,000

57,000

175,000

498,000

Dverell Total Cost

$2,670,000$ 


\subsection{Adaptab111ty of Housing Systems to Total Energy}

Nineteen of the twenty-two housing system producers will be bullding dwelling unfts on the s1x BREAKTHROUGH sites under consideration in this report. The number of different systems on one siteranges from three on the Jersey City and Memphis sites to elght on the Indlanapol1s ste.

Constructions that provide cavity walls or sandwich constructions made of wood, foamed insulation, grpsum board and other materlals that can be readily cut provide the greatest flexiblitty in introducing condults and ducts into the structure. Constructions of masonry and concrete

10 panels that provide for pipe chases at the joints offer an intermedlate level of plexib1lity for conduits for electricity, water and dralnage systems. Factory prefabricated volumetric modules must in most cases incorporate a completely preplanned arrangement of servlce systems, especially if made of masonry.

Every dwelling unit must provide for distribution of electric1ty and domestic hot and cold water; and for an adequate drain, weste, and vent system, whether the site is equipped with a total energy system, central or individual heating and cooling systems. If individual heating and cooling units are used, electricity and gas or oil must be brought to this equip-

20 ment. If a total energy system or a central hot-and-chilled water system provides for space conditioning, two to four water plpes of relatively small size and electric service must be brought to the central unit in each house. These additional plpes (one to three) can readily be accomodated in cavity walls, pipe chases at panel joints, or in the speclal ut1lity 25 chases that must be provided in volumetric nodule housing designs. Thus the adaptation of the total energy concept to the variety of proposed 
houslng systems does not appear to offer any new or major type of design probler.

\subsection{Communt ty Development}

The addition of retall stores and certaln types of community

development to the load on a total energy system 18 usually considered to be advantageous because 1 t ralsea the electrical load factor of the system and permits a larger fraction of the thermal energy requirements of the develupment to be provided from recovered waste heat.

Only the Jersey $\mathrm{C} 1 \mathrm{ty}$ and Macon developents Incorporated any retall 10 fac1lit1es, with the Jersey C1ty floor area belng larger by a factor of at least five. The comuntity fac1litles planned for the Jersey C1ty ofte are as foliows:

$$
\text { Retall stores }
$$

Schools

15

20

tem with respect to thermal enviroment, nolse and vibration inside the plant; the transmission of nolse and vibration to the surrounding occupled space; and the likelthood of creating unacceptable alr pollution in the commun lty.

VIslts to several Installations of total energy systems ind icated 25 that nolse and vibration control was essential in a residential communty. Excessive nolse and vibration transmission from a total energy plant can 
occur by direct transmission of engine room nolse through windows, 1ight-

welght walls, and englne room ventllation ducts; from the pulsatiog exhaust of reclprocating engines; from alr or water flow in the cooling tower; and by transwisition of vibration through the foundations of reciprocating or

5 rotating machinery to surrounding bulldings. All of these features of nolse and vibration control require specific attention in the design of the plant, but none 18 an insurmountable problem.

Federal, state, and municipal limtations on the amount of particulates and sulfur dioxide that may be discharged into the atmosphere

10 with comburtion gases egsentlally dictate the use of gas or No. 2 fuel ofl in residential areas. The problems of fuel storage, ash handing, and particulate and ulfur dloxide discharge make it 1mpractical to use coal In a total energy plant on a BREAKTHROUGH site. Combustion gases from a gas- ollburning plant wust be discharged at a helght that w1ll promote 15 diffusion into the upper atmosphere and at a location that w11l not allow the prevalling winds to carry them into nearby dwellings, recreation areas, or other occupled spaces. L1kewsse, the water vapor emanating from the cuoling tower should nut create objectionable mist, fog, or frost deposits In occupled areas or trafflc areas of the site. These latter problems

20 related to discharge of combustion gases and water vapor dissipation are no different for a total energy plant than for a conventional central hoating and alr conditioning plant.

\subsection{Energy Resources}

There are inadequate reserves of electric power generating capacity

25 In wide areas of the United States. Especially critical are the eastern seaboard states from New York to Flor1da and the c1t1es of Ch1cago, St. 
Lou19, Minneapol1s, and St. Paul. $10 /$ The electrlcal power shortage emphasizes the relevance of a study of alternative ut $111 t y$ optione for new housing developments. Concurrently, there are shortages of natural 8as. In Balt 1more no new Industrlal customer can obtain natural gas service if his requirements 5 exceed 300,000 cu ft per day, and no current customer can 1ncrease h1s requirements by more than 300,000 cu ft per day, whereas in Washington, D.C. no new customers can be connected at all. The 1mportation of gas from Algerla and Canada 18 being lamplemented, but 18 not expected to meet the growing demand.

Hecause of insufficlent reserve generating cepactity in several areas of the country, the application of total energy yatems to the BREAKTHROUGH sites In Jersey Clty, St. Louls, Memph1s, and Macon may serve as good and prudent examples of conservation of scarce resources in these particular areas as well as worthwhle experiment for wider consideration. The gas ut111ty 15 serving Jersey C1ty lo not able to furnish gas for a total energy plant at that slte. Since fuel oll 18 a little cheaper than gas in Jeraey City at the present time, and because New Jersey is near the end of the gas distribution plpeline from the Texas flelds, Jersey Clty would be a good cholce for an experimental o1l-burning total energy system. There appear to be adequate 20 gas reserves at Macon. Memph1s, and St. Louls for the BREAKTHROUGH s1tes. 3.10 Site Planner and Developer Att 1tudes toward Total Energy Systems

The site planner and developer for the Macon site have shown the greatest inftiative and interest in the application of a total energy system to the BRFAKTHROUGH development. In fact, the planner proposed that they 25 be authorlzed to make a feaslb1l1ty study, produce a design, and carry out fleld studies of performance after installation. 
The olte planner for the Jersey C1ty site expressed a positive attitude about a total energy system there, and was encouraged and supported in this approach by one of the housing system producers. This producer envisions replacing an inftial ruel-burning total eners system In few years with ruel cells as alrect means for converting chemical energy lato electriclty. Tuel cello are not eufficleatly developed es yet.

The site planoer at $8 t$. Lou1s was w1lling to consider the instarlation of a total energo system provided 1t did not entall higher capital cost for the developer and did not delay the t1me schedule. RouseWates, the only housing system producer on the eastern parcel of tbe st. Louls site, had a feeslb111ty study of total eneror and several other ut111ty aystems made to determine economic reesibility. That study and a second study of the econoulc seasibllity of a total energy plant on the Rouse-Wates development reached contradictory conclusions.

The planner and developers at the Memphis, Sacramento, and Ind1anapol1s sites took no inftlative in exploring or prowoting application of total energ syotems to their respective developments. 


\section{Recomendations and Implementation}

When the foasblitty study was made two reara ago, none of the BRRAKTHROUGH sites were under construction and the types of bulldings, the materlals to be used, and the houlng syster producers were in an early stage of Identification. The stes at Memple and Jersey C1ty were recommended as the two beat stes for a total energy plant, partly because they would have the largest number of dwelling unlta, a high denelty of dwelling units, and more high-rlse construction than the other sites. Jersey City was given preference because it was to have the only large 10 amount of comerclal development, and because the planner and one of the housing system producers were interested in the use of a total energy system. Jersey City did not then have a particularly favoreble rat1o between the costs of fosell fuels and electricity.

As the design and construction of the varlous BRRAKTHROUGH 1 tes

15 have developed, the number of dwelling unite at Memph1s has been reduced by 21 percent and the percentage of high-rloe untts has been lowered from 61 to 55 whereas the percentage of high-rise units at Jersey C1ty has risen from 43 to 98 .

The costs of all fuels have rlsen signiflcantly since mid-1970. The 20 price of electricity has risen more than thet of oll and gas, and the price of oll has risen the least -- 10 percent or 1ese in the $1 x$ c1t1es considered in thlo study. Gas wa not avallable in Jereoy C1ty for a total energy plant so the plant has been deslgned for o1l. The rat1o of prices between 011 and electric1ty in Jersny City hes become wore favorable to the installation of a total energy plant during the last two years. 
The houlag and the total energy plant at the Jersey C1ty alte are under conotruction at the present t1e and occupancy 10 expected for the oprag of nat yeer. Another paper la thlo confereace describes 5 the detalle of the fleld studies that w11 be ande on this site and the Latruatetion to be used for patheriog performace date. 


\section{References}

1. Total Energy, D1rectory and Data Book, Vol. 9, No. 1, Jan,, 1972.

2. Newe Iteme, Ge Competition, Southern Services, Inc., B1rmingham, Alabama, Jan., Peb., March, 1970.

3. ASHRAE Handbook of Pundamentale, Chap. 22, 1967.

4. Englneering Weather Deta, A1r Porce, Arey, and Nevy Manue1, AF-88-8, Chapter 6, NAVPAC, P. 89, July, 1967.

5. Monthly Normel Temperatures, Preclpltet1on, and Degree Daye, Techn1cal Paper No. 31, U.S. Weather Bureau, Nov. 1956.

6. An Integrated Ut111ty Syeten Concept, Robert V. Ayres, et al, IRT-N-95, Internat lonal Revearch and Iechnology Corp., Wach1ngton, ה.C. Apr11, 1970.

7. An Am lyels of Electric Energy Usage In Alr Porce Houses Equipped with A1r-to-A15 Reat Pumpe, Paul R. Achenbach, Joseph C. Davis and W111Lam I. Sm1th, Monograph 51, National Bureau of Standarde, Washington, D. C., 1962.

8. Residential Energy Consumption, H1ttmen Aseoclated, 1972.

9. ASHRAE Gulde and Deta Book, Syotere Volume, 1970.

10. Warning: Low Voltage, Nergerek, May 18, 1970. 

DESCRIPTION OF EQUIPMENT AND INSTRUMENTATION FOR A

FIELD STUDY OF A TOTAL ENERGY SYSTEM IN AN APARTMENT DEVELOPMENT

By

J. B. Coble and P. R. Achenbach

National Bureau of Standards

Washington, D. C. 20234

\author{
presented at \\ 7 th Intersociety Energy Conversion Engineering Conference \\ San Diego, California \\ September 25-29, 1972
}




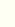


DESCRIPTION OF EQUIPMENT AND INSTRUMENTATION FOR A FIELD

STUDY OF A TOTAL ENERGY SYSTEY IN AN APARTMENT DEVELORIENT

By

John B. Coble and Paul R. Achenbach

ABSTRACT

The Department of Housing and Urban Developnent selected the BREAKTHROUGH site at Jersey City, N.J. as the location for an installation and fleld study of a total energy system. This development covers six acres, and is comprised of four bulldings containing 488 dwelling units, a small

10 buflding for commerclal use, two small schools, a swimming pool, and the. total energy plant. The field study of this installation is being carrled out by the National Bureau of Standards to produce muchneeded authoritat 1 ve information on engineering performance, maintenance requirements, and load-and-cost data for total energy systems.

15 The central plant and the Individual bulldings are being extensively instrumented to provide digltal data on fuel utllization, the generation of electrical and thermal energy, the excess heat rejected, and the utillzation of electrical and thermal energy by all major segments of the load. A separate analog data system is being exployed to obtain recordings of 20 transient conditions of voltage, frequency, current, power factor, and load division during sudden load changes and to record interruptions of service due to overload or malfunction of equiprent. The environmental impact of the total energy plant with respect to noise, vibration, alr pollution, and aesthetics is also being evaluated.

25 KEY WORDS: data acquisition system; electrical power system; energy conservation; fuel ut 111 zation; thermal efflclency; thermal energy system; total energy system; utility system performance; waste heat recovery. 
DESCRIPIION OF FQUIPMEST AND INSTRUMENTATION FOR A FIELD

STUDY OF $\wedge$ TOTAI. FNERGY SYSTE.Y IN AN APARTMENT DEVELOPMENT

By

John B. Coble and Paul R. Achenbach

1. Introduction

5

National Sureau of $S t a n d a r d s$, under sponsorship of the Department of Hous1ng and L'rban Development (HUD), for analyzing the performance of a 3 megawatt total energy system on the Operation BREAKTHROUGH site at Jersey C1ty, N. J. On this six-acre site, electrictty and energy for heating and cooling will be produced by a central plant us ing number two fuel oll in diesel eng1ne10 generators and bollers. The site has 488 residential dwelling units in four medlum- and high-rise bulldings. Also on the site are a school, preschool, commercial areas and a swlmming pool. The National Bureau of Standards is Installing an extensive data-collection system to analyze the electrical and thermal performance of the cotal energy plant and the energy 15 use by the bulldings of the development.

When the National Bureau of Standards started th1s program in Apr11, 1970, very little data on the economic and engineering sopects of total inergy sygtems had becn published. Most total energy systems were in-

20 stalled in areas where the price of natural gas was low enough relative to thc cust of clectrlcfty to make such a system attiactive to the client. Many systems were operated by the mafntenance staffs of the local gas ut111t1es. Since the majority of these plants have less than one megawett installed capacity, only enough instrumentation was installed for operational

25 purposes. In most cases, the instrumentation was inadequate for an eng1neering determination of thermal efficlency, load diversity, and rellability. 
The continuing depletion of gas reserves and the widespread shortage of reserve electrical generating capacity in the United States made it highly desirable to determine the potential of a total energy system for providing rellable thermal and electrical utllity service to new develop5 ments with lower usage of fuel. Consideration was given to the Instrumentation of an exlsting total energy plant for this study. However, it would have been difficult to place the flowmeters, temperature sensors, and electrical Instruments Into an exlsting system. Purthermore, such a study would have constituted an after-the-fact determination and disclosure of the en-

10 gineering, economic, reliability, enviromental, and maintenance aspects of a system not designed in response to a performance specification and not intended for such detalled enalysis.

By contrast, the BREAKTHROUGH program of the Department of Housing and Urban Development offered an opportunity to analyze widely distributed 15 Sites for their suitability for a demonstration plant. The financial and management guidelines for the BREAKTHROUGH program also provided considerable latitude in spectfying the desired performance of the system and the degree to which it would be instrumented and evaluated.

After feasibility studies of eleven BREAKTHROUGH sites for the In20 stallation of a total energy plant had been completed, and the Jersey City site had been selected, a performance specification for the plant was prepared. This specification set forth, in performance lengusge, the requirements for the plant with respect to loed determination, stendby capacity, system reliabllity, stabllity of electrical services, main25 tenance, safety, and 1 ts environmental Impact in terms of noise, vibration, alr pollution, magnetic interference suppression, and aesthetic 
treatment. Ihis performance speciflcation became a part of the guideline documents for the englneertng f1rm, "Gamze-Korobk1n-Caloger", which then designed the demonstration plant. The fcasibility study is described in another paper'being presented at this conference. used for a demonstration installation of a pneumatic trash collection system (PTC) sometimes also called a vacuum solld waste collection system. This system was designed by another firm using a separate spec1fication and is the subject of another paper. However, the solld waste collection, 10 compaction, and loading equipment will be combined with the total energy plant in a single central equipment bullding. Figure 1 shows the locations of the bollers, chillers, engine-generators and the pneumatic trash collection system in the central equipment bullding, which is approximately 50 feet by 143 feet in size.

\section{S1te Ut111ty System}

15

All electrical and thermal energy for the Jersey c1ty s1te w111 be produced on site. The electricity will be generated by diesel-engine-driven generators. Hot water for space heating and domestic hot water w11 be produced by recoverable waste heat from the engine-generators and by two supplementary bollers. During the alr-conditioning season, hot

water w11 be used in absorption refrigeration machines to produce ch1lled water. The electricley, heating hot water and chilled water w1ll be distributed to the bulldings on the slte through underground condults. Ftgure 2, a schematic of the site, shows the location of the electrical, 25 chilled and hot water, and penumatic trash collection systems. 


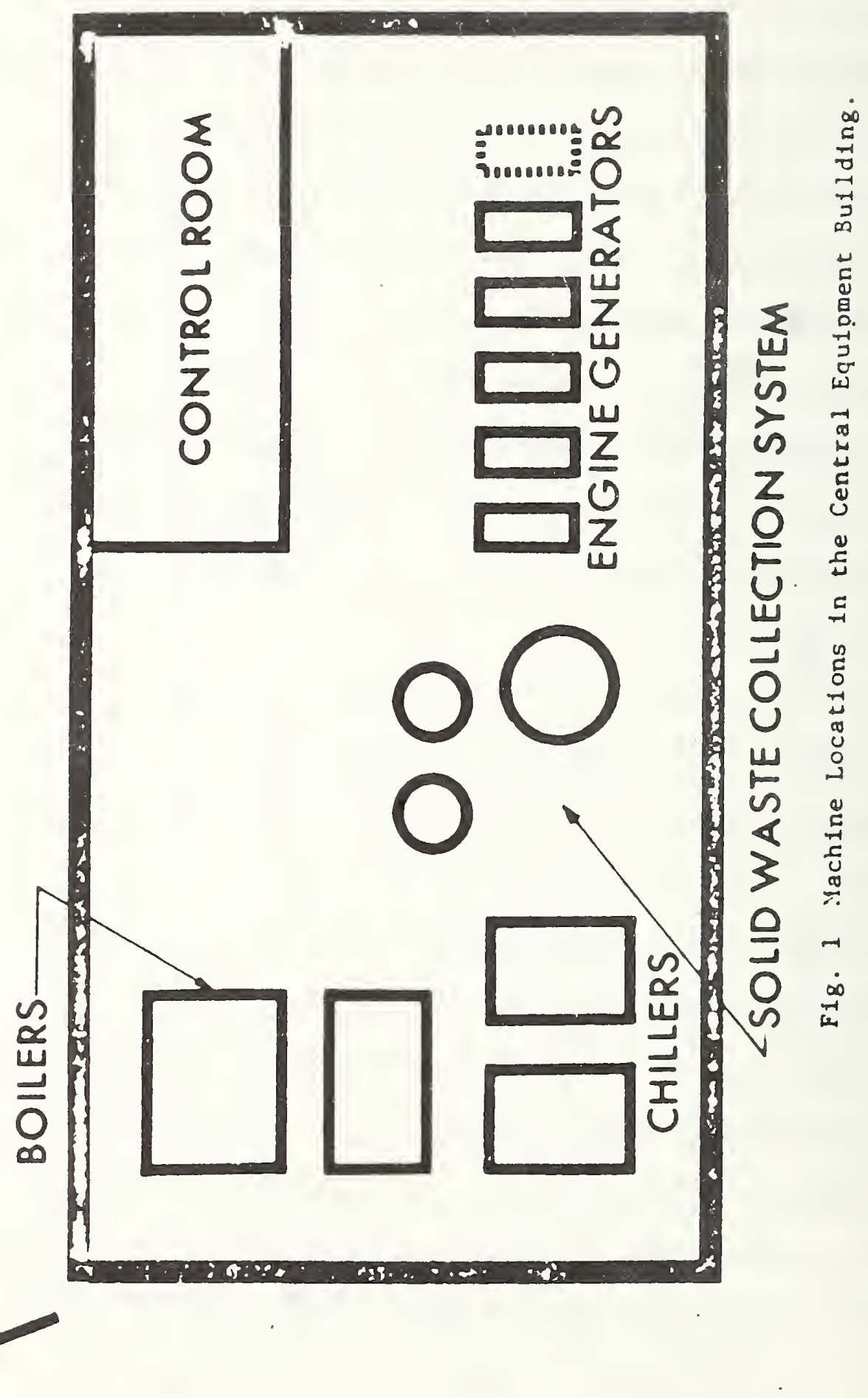




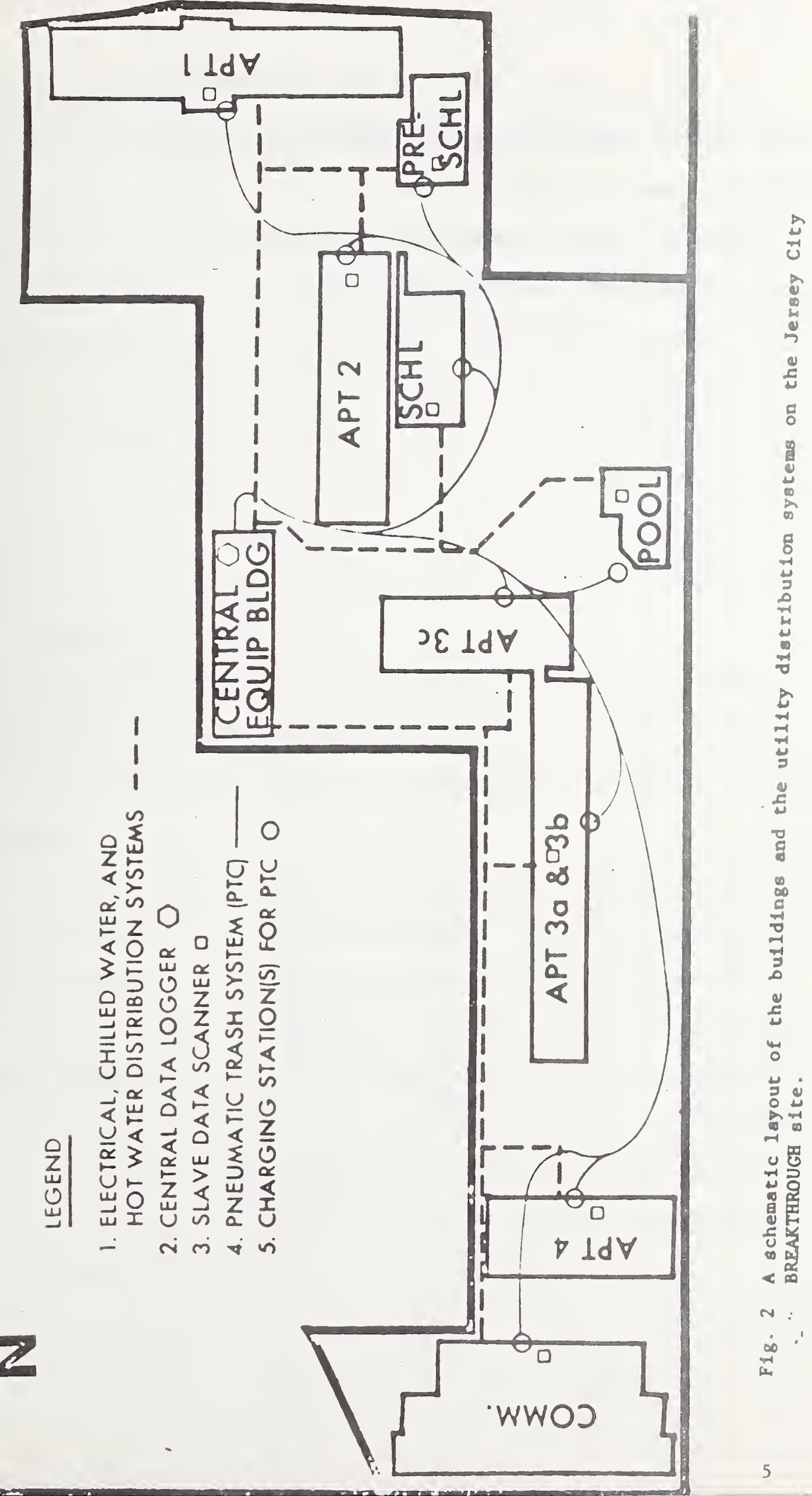


The central pneumatic trash collection system will pull all trash from the ite into a single compactor-type receptacle in the central equipment bullding.

Electriclty at 480 volts, 60 hertz, three-phase, will be distributed from the total energy plant to each bullding. 


\subsection{Eng1ne-Generators}

The central ut1lity bullding w1ll contaln flve 600-KW englne generators. each rated 480 volts, three-phase, 60 hert 2,750 KVA at 0.8 p.f. The eng1nes are rated at $860 \mathrm{HP}$ and are designed for ebullient cooling. However, the

5 engines w111 be water-cooled, and are designed for a flow rate of $300 \mathrm{gpm}$ of primary hot water entering the fackets at $225^{\circ} \mathrm{F}$ and leaving at $236^{\circ} \mathrm{F}$ under full load conditions. About $43 \%$ of th1s water (130 8pm) w111 be clrculated through the exhaust heat recovery muffler, where $1 \mathrm{t}$ w11 be heated from $236^{\circ} \mathrm{F}$ to $252^{\circ} \mathrm{F}$. The water leaving the heat recovery muffler 10 will be mixed with the remaining jacket water and will enter the primary hot water loop at about $241^{\circ} \mathrm{F}$. Flgure 3 shows the primary hot water system In the central ut1lity plant.

During the warmest and coldest months of the year, the heat recovered from the engine-generators w11l provide from 40 to $50 \%$ of the 15 total thermal requirements, whlle the remainder will be supplied by the bollers.

\subsection{Bo1lers}

Two bollers, each rated at $13,390,000 \mathrm{Btu} / \mathrm{hr}$, w111 supply all of the heat not obtalnable from the englne-generator recovery system. The bollers w11 be installed in serles with each other and with the englne jacket 20 water c1rcult, as shown in Flgure 3 and are used to "top off" the primary hot water temperature. The control systen senses the ch1ller and hot water heat exchanger loads to malntain the primary hot water in the range from $225^{\circ} \mathrm{F}$ to $245^{\circ} \mathrm{F}$. During perlods of low hot water usage, the bollers w11 not be used if enough heat 18 provided by the heat recovery system 25 on the englnes. 


\subsection{Absorption Ch1llers}

Two 526-ton absorption chiller w11l provide chilled water for alr conditioning of the entire site.

The absorption chillers are to be installed in parallel. The chilled 5 water control system controls the operation of the chillers as the load demands. Each chlller requires 826 gpm of primary hot water entering at $245^{\circ} \mathrm{F}$ and leaving at $222^{\circ} \mathrm{P}$ to produce $936 \mathrm{gpm}$ of chiller water leaving at $44^{\circ} \mathrm{F}$ and returning at $58^{\circ} \mathrm{F}$ under full load conditions. The chillers require a constant volume of primary hot water and will use a 3-way valve 10 to modulate the hot water temerature during low londs.

\subsection{Dry Coolers and Heat Dume}

When one or more englne-generators are operating to satiofy the electrical requirements and there 18 l1ttle need for elther space heat1ng or cooling, the return water to the englne Jackets may become too hot for safe

15 engine operation. Two dry coolers (water to alr heat exchangers) connected In parallel, have been provided in the design to dispose of excess heat. These dry coolers w111 be mounted on the roof and are equipped with fans that operate whenever the return water entering the engine Jackets reaches a remperature of $230^{\circ} \mathrm{F}$. If, for any reason, the fans in the dry coolers 20

fall to operate, a second set of heat exchangers (heat dump) cooled by c1ty water, w11l be activated when the return facket water reaches a temperature of $235^{\circ} \mathrm{F}$.

\subsection{Electrical Distrilution System}

Electricity will be distributed by a three-wire delta system with 25

two separate feeders serving each bullding on the site. One feeder, labeled a normal load feeder (PN), w1ll supply electriclty for the individual 
dwelling unts, miscellaneous power, and for all elevators except one in each bullding. The second feeder, labeled an essential load feeder (PE), w1ll supply power for the corridor and stalnay 11ghting, one elevator in each bullding, heating and cooling water pumps, sump pumps,

5 domest1c water pumps, and flre pumps. The sump pumps, heating and cooling water pump, and domest1c water pumps, w1ll be electrically interlocked wth the flre pumps to limt the demand on the distribution and generation system.

Three motor control centers (MCC) and one lighting power clrcult

10 (LP 1) w111 furnish all of the electric power for the aux1l1arles and lighting requirements of the central equipment bullding. A separate feeder (PTC) w1ll furnish electric power to the pneumatic trash collection system in the central equipment bullding (See Flgure 4).

The clrcult connecting the total energy syotem to the muntclpal

15 power system w111 normally be open. Th1s switch, 111 lutrated In P1gure 4, w111 be closed in case all of the flve englne-generators are 1noperative and have been shut down. Only enough power would be taken frow the munfcipal system to serve the essential load c1rcults on the s1te.

\section{Data Collect1on Syctem} The total energy system at Jersey City 18 belng extensively instrumented to produce englneer1ng, rellab1l1ty, malatenance, and loed-and-cost data that are not generally avallable at the present tlme. It 18 anticlpated that the data collected from this Installation can be rellably extrapolated to larger housing developments, other cllmates, other fuel cost oltuations, 25 and gome other bullding occupancies. 


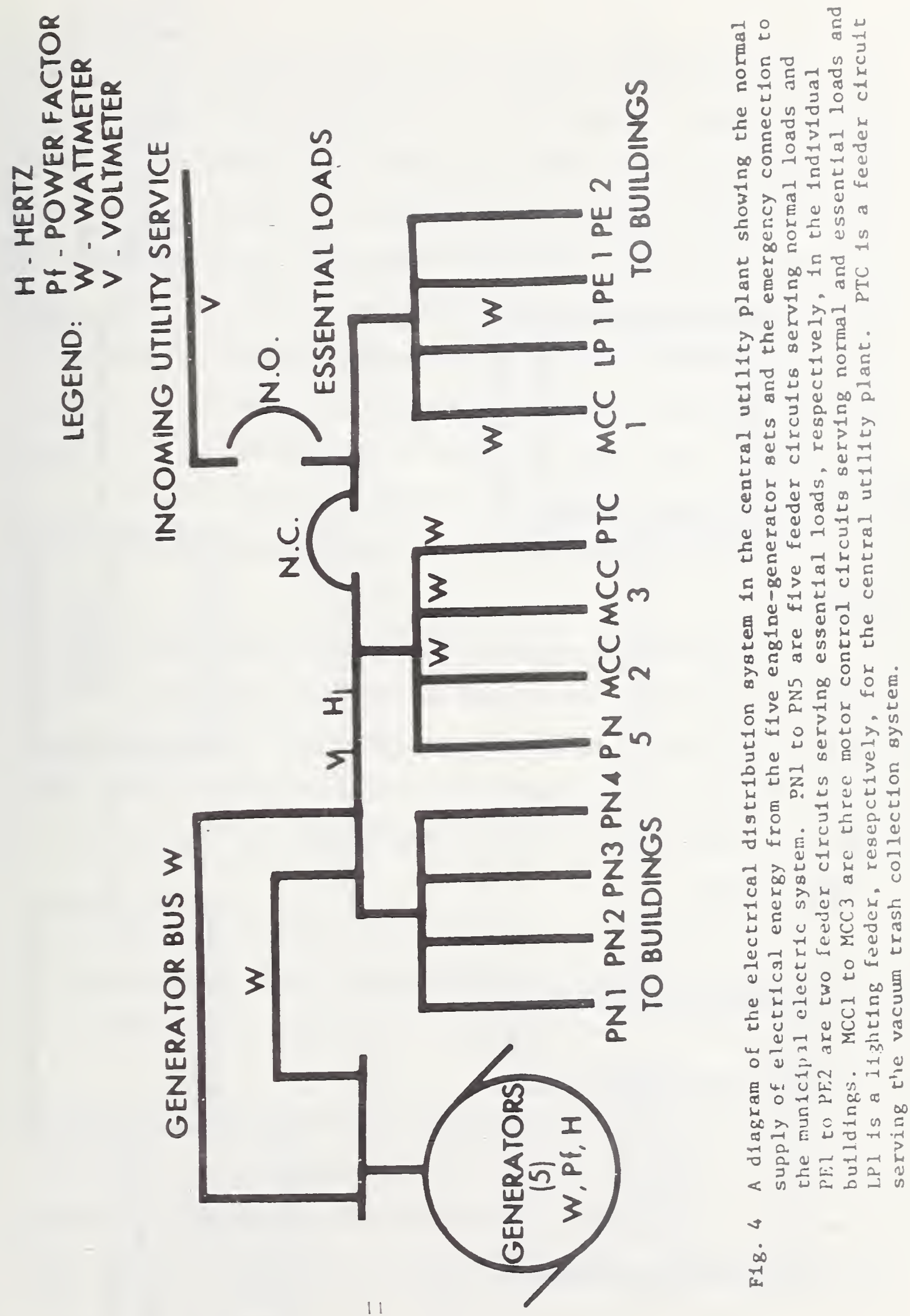


The instrumentation being Installed w11l provide for detalled analysis of the fuel used, the electrical and thermal energy generated, the ut111zat1on of energy by all major segments of the load, the performance of all major plant components, the stab111ty of the electrical service, the rellab111ty

5 of the several services, maintenance requirements, environmental conditions In and near the plant, fuel and operating costo, and weather data. The target end-to-end accuracy for th1s measurement system is $1 \%$ which means that the individual transducers need to have accuracles on the order of $0.1 \%$ to $0.25 \%$. Th1s level of accuracy 18 1mortant because of the large 10 number of integrated measurement of energy use that are required. The data collection system 18 comprised of two major components; name $1 y$,

a) a central data logging system that w11 scan, transmit, and record 300 channels of data on magnetic tape every five minutes. This 15 system collects data directly from the central plant and via satell1te unlts from each of the bulldings on the site. The satellite units tranomit data on electrical and thermal energy usage to the central data logg1ng system.

b) an analog system consloting of a strip chart data logger to

20 record translent varlations in the electrical service, interruptions of the utility services, and malfunctions or overloads on the system.

\subsection{Central Data Logging System}

The central data logging system 18 installed in the central ut1lity bullding. It scans and records the 300 data channels in the power plant

25 at a rate of up to 30 channels per second. The components of the central data logging system are shown on Figure 5 . The central controller directs 

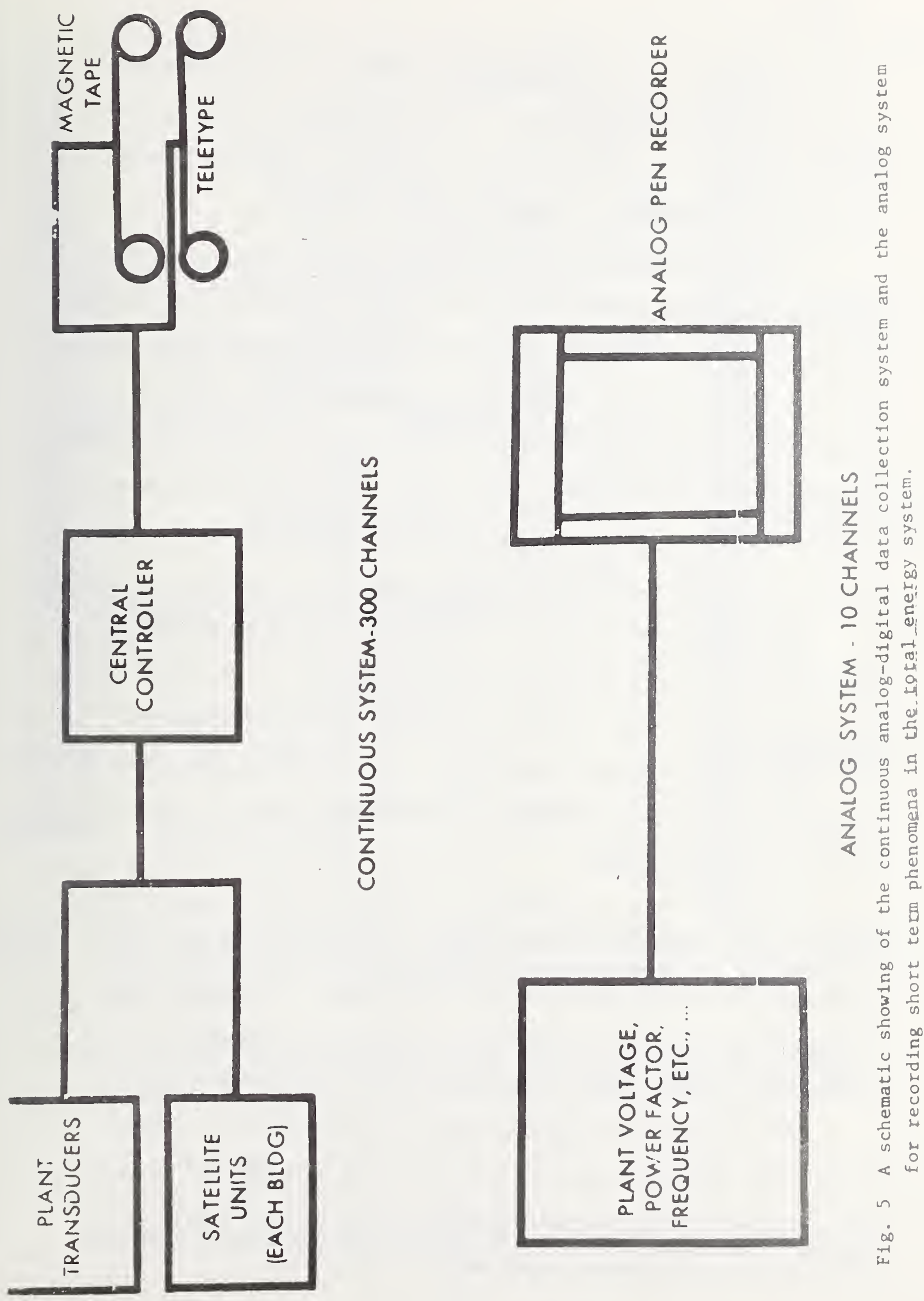
system operation including sequencing of channels for an, ocan rate, analog to-digltal conversion, etc. The master scanner output of the central controller is printed every flve minutes on magnetic tape or optionally on a manually-controlled teletype printout.

In sequence and as part of each central ut1lity plant scan, the central data logging system controls the oatellite un1to so that the data channels in each bullding are recorded on the central data logsing system. The satellite units do not record data. On algmal from the central controller they 8 can the electrical and water flow meters and the temperature sensors in each bullding every flve minutes. The actual date retrieval requires only about one second per bullding. Thlrteen channelo of data are to be recorded, but the system 18 expandable to 30 channelo per bu1lding. Figure 6 shows a schematic of the typlcal electrical and piping system, Including data collection instrumentation in each bullding. The data collection system is designed to measure and record integrated electrical energy usage and instantaneous readouts of the flow rates and temperatures of chllled water, heatine hot water, and domestic hot water in each 3.1.i Electrical Metering building.

Flgure 4, a one-line diagram of the electrical diatribution system in the central utlity plant also shows the location of the electrical metering points in the central equipment bullding. On both the normal PN1-to-PN5 and essentlal PEI and PE2 load feeders, energy usage w111 be measured and recorded every five minutes in the individual bulldings.

The instantaneous electrical power will be measured by a "Hall effect" watt tranoducer, and the energy use w111 be Integrated by an auxiliary device being designed and bullt at the National Bureau of Standards. The wattmeters are to be installed on the 208-volt four-wire (WYE) side of the bullding transformers. 
In order to analyze the quality of electrical service, the line voltage on the 208-volt side of the transformers w111 be recorded continuously. It was decided to record the secondary rather than the primary voltage because the secondary voltage 18 more responslve to load phenomen in the 5 bullding. The primary voltage depends more on what happens in the ceatral utility plant.

\subsubsection{Water Metering}

The flow rates of chilled and hot water, and the return temeratures and temperature differences, w11 be recorded at 5 minute intervalo 10 each bullding. Most water flow rates are to be mesoured by venturl meters using an electronic differential pressure cell as the flow transducer. Thermocouples are to be used to measure the actual temperatures of the hot and chilled waters entering the bullding. Thermoplles w11l be wed to wessure the temperature differences of the hot and chllled water entering and leaving the bullding. The actual leaving temperatures w11l be calculated during data analys18. (See Flgure 6)

For large water flow rates venturl meters were selected because they are senstive to the anticlpated minor varlations in flow rates and they have high efflclency and low pressure drop under these conditions. The ASME standard venturl meters were selected rather than the short-form venturl meters or orlfice plates because of ereater metering accuracy for flow meas urement .

The maximum inaccuracy of each venturl meter in the destgn flow range 1s specifled as $\$ 0.25 \%$. Each ventur1 meter was 1nd1vidually callbrated and has a callbration curve over the design flow range. In order to obtain accurate pressure-drop data from the venturl flowmeters, electronic d Ifferential pressure cells were selected. These cells have an error 
of $\pm 0.10 \%$ or less. The differential pressure traneducers generate a dc voltage which is proportional to differential presare.

Turblne flow meters will be used on plpe lines smaller than two Inches, and on the domestic hot water plping in the comercial, achool, and pre-school bulldings. These meters w1ll be protected by 5-micron mesh s.tralners and have an error of $+0.10 \%$ or less. A pulse counter 18 to be used to convert the turbine pulses to volume flow since each pulse corresponds to the passage of a known amount of water by cal1bration. The "pulse counter 1 gnal is converted from digltal to analog mode, providing a dc voltage that is proportionel to integrated count total. Turblne flow meters were considered for the larger plpe alzes but were ruled out because of high cost. However, turblne flow wers for the saller pipe sizes cost less than venturl weters f1tted with the electronlc different1al pressure cells.

15

\subsubsection{Temperature Measurement}

All temperatures are to be measured by callbrated copper-conetantan thermocouples, using an electronlc reference function. The thermocouples transmit a dc voltage wh1ch 1s proportional to the actual temperature.

Temperature differences are to be masured by mult1-junction differential thermopiles in order to obtain higher dc voltagea for the small temperature differences I1kely to occur. The de voltage output 1o proportional to temperature difference. The temperature measurement system w11 have the potential of measuring differential temperatures as 8 mall as $0.05^{\circ} \mathrm{F}$.

254.2 Analog Recording

The analog strlp chart recorder system w1ll record all abnormal performance in the total energy plant, 1ncluding transient electrical 
characteristics, englne malfunctions, operation of any of the safety or protective devices on the aystem, and the tlme and duration of overloads on the electrical system.

As an example of 1 ts function, whenever the voltage on the maln bus

5 drops ten percent below rated voltage, the electrical control oystew goes Into a "system dump" sequence. Th1s system-dump algnal otarts the anelog recorder. During the system-dump sequence, all electrical loads except the essentlal loads are disconnected sequentlally; that 18, the normal feeders to the bulldings, the alr conditioning system, street 11ght1ng,

10 etc., unt1l the functioning generators are able to carry the remolning load. If the voltage keepa dropplng, the total energy plant w11 be shut down and the emergency publ1c ut1lity feeder for the easent1al loads of the site w11l be energlzed. The total energy plant w111 remain shut down untl manually checked and restarted. If durlng system-dump sequence

15 the voltage stabll1zes, all services will return automatically to normal operation. The analog recorder w11l record the electrical transients and generator phenomena during the overload perlod.

\section{Spectal Data Collection Surveys}

\subsection{A1r Pollution}

The environmental effects of the total energy plant are part of the fleld study. During the design stage, the National Bureau of Standards studied existing and proposed regulstions concerning emissions from diesel-operated power plants, in order to comply with afr pollution regulations and to avold nelghborhood complaints. 
For sulfur dioxide emission control, the State of New Jersey limits the amount of sulfur allowed in the fuel to $0.2 \%$ by weight for No. 2 fuel oil and lighter o1ls. - For plant emlsstons, New Jersey has only a smoke requirement of No. 2 Ringelmann on boiler stack emissions. However, the New Jersey Air Pollution Control Administration has proposed a "no visible smoke emission" requirement from boilers and diesels. $3 /$ The Environmental Protection Agency (EPA) has no regulations covering this plant, because of its small size. The EPA alt pollution regulations cover all plants down to $250 \times 10^{6} \mathrm{Btu} / \mathrm{hr}$. $4 /$

10

15

1/ New Jersey Alr Pollution Code, Chap. 10, Sulfur in Fuels, 5/1/68 $0.2 \%$ sulfur effective $10 / 1 / 71$.

2/ Ibid, Chap. 4, Smoke 1/1/58.

3/ Proposed Chapter 4, N. J. Alr Pollution Code, 1/15/71.

4/ Federal Reglster, Vol. 36, No. 159, August 17, 1971, p. 15706. 
The California truck diesel-englne emlssion atandards $1 /$ for 1975 were the only standards avallable for study of exhaust pollution requirements for diesel prime movers. The limitations contalned in these standards

5 include the following:

1) hydrocarbons and oxides of nitrogen--5 grams per brake horsepower hour;

2) carbon monoxide--25 grams per brake hor sepower hour. The Callfornia emission requirements made no reference to diesel-englne driven stationary power plants--only to dlesel engine-driven vehicles.

The specification prepared for the engine-generators to be installed In the Jersey City total energy plant cited the following maximum values for exhaust emissions at a generator loading of $600 \mathrm{KN}$ :

1) unburned hydrocarbons - 35 grams per hour;

2) carbon monoxide - 700 grams per hour;

1) nitrous oxides - 4500 grams per hour;

4) particulate matter -40 grams per hour;

5) smoke - - No. 1 Ringelmann maximum.

The emissions of each englne will be measured during pre-acceptance factory testing, and agaln during the on-site acceptance tests.

1/ Callfornia Exhaust Em 1881 on Standards, Test and Approval Procedures for Diesel Engine-driven vehicles in 1973, and subsequent Model Year Vehicles, Over 6,001 Pounds Gross Vehicle We1ght, 11/19/70. 
In addition, total emissions from the total energy plant will be measured. Exhaust emission sampling will be performed according to the Environmental Protection Agency standards I/. Alr samples at several locations on and adjacent to the site will be measured at selected time 1ntersals. An alr sampling survey of the site wlll be made before site operation. Th1s survey w11l be the base line for comparison with future air-sampling surveys.

4.2 Nolse Leve 18

Total energy plants can produce excessive nolse outside the plant 10 bullding unless properly deslgned. At one total energy plant, the Nat Ional Bureau of Standards recorded sound pressure levels for Informational purposes. It was found that the sound pressure level Inside the equipment room between two englne-generators was $104 \mathrm{~dB}(\mathrm{~A})$. On the roof of the same total energy plant about 30 feet from the cooling tower, the 15 sound pressure level was $68 \mathrm{~dB}(\mathrm{~A})$.

The NBS performance spectflcation for total energy plants required that portable or permanent acoust1c treatment be used to prevent exposure of working personnel to sound pressure levels in excess of $85 \mathrm{~dB}(\mathrm{~A}) \stackrel{2}{ }$ /. In the control room the sound pressure level was $11 \mathrm{mited}$ to $70 \mathrm{~dB}(\mathrm{~A})^{2}$ '. 20 After the Jersey City site 1 s occupled and the total energy plant is operating, a sound pressure level survey of the site w11l be conducted. The results of this survey w1ll be compared to the sound survey shown on Fig. 7, made on that site by the National Bureau of Standards in September, 1970. Th1s survey was conducted over a 72-hour period (Thursday,

25 I/ Pederal Register, Vol. 36 No. 247, December 23, 1971, "Protection of the Environment, Standards of Performance for New Stationary Sources".

2/ A Performance Specification for a Total Energy Plant at the Jersey City BREAKTHROUGH I Site, P.R. Achenbach and J.B. Coble, NBS Report 10313 (Dec. 1970). 


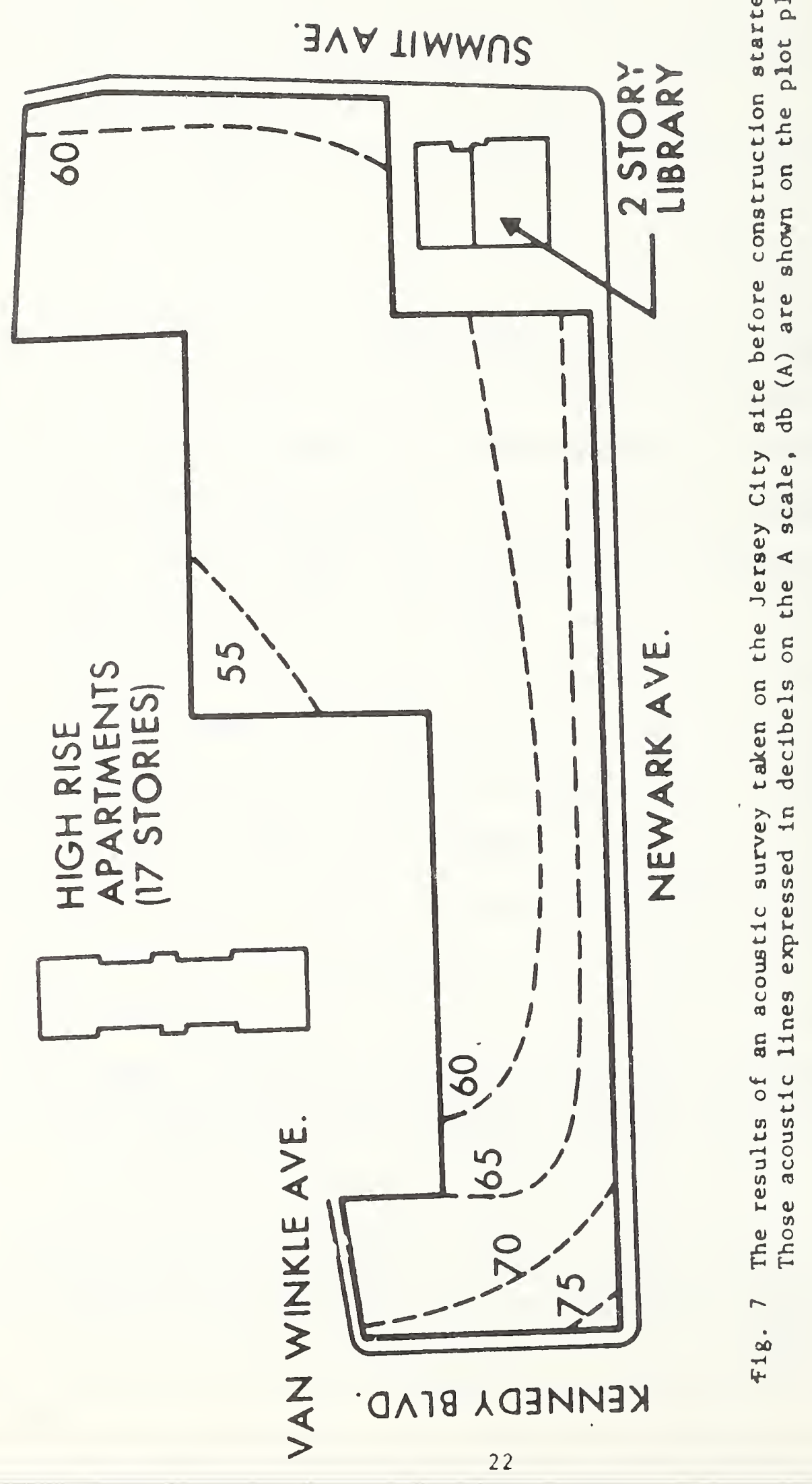


Friday and Saturday) and shows that the average sound pressure levels ranged from 55 to $75 \mathrm{~dB}(\mathrm{~A})$ during the survey perlod. The higher readings were observed near the street where trucks and buses were the mojor notse contributors. The total energy plant is being installed where the meas5 ured sound pressure level approximated $55 \mathrm{~dB}(A)$. The allowable increase In sound pressure level over amblent sound pressure level due to operation of the total energy plant was limlted to $5 \mathrm{~dB}(\mathrm{~A})$ in the porformance specification.

In order to comply with the specifications, extensive acoustical

10 treatment 18 belng provided for the englne exhausts. The waste heat recovery muffler is designed to reduce the sound level by 13 decibels in the frequency band of $4800 / 10,000$ cycles per second. The exhaust muffler on the stack 18 designed to reduce the exhaust nolse by 26 dec1bels in the frequency band of $37.5 / 75 \mathrm{cycles} / \mathrm{sec}$ and by 23 declbels in the frequency

15 band of $4800 / 10,000$ cycles/sec. Acoustical treatment is also being provided for the cooling towers which are mounted on the roof of the central ut111ty plant. 


\section{Summary of Pleld Studies}

The planned fluld studies are comprised of the following mojor subdivisions: (a) an energy use study, (b) performance of the principal plant components, (c) stability of the electrical service, (d) reliability of

the services, (e) environmental conditions at the total energy plant, and (f) owning and operating costs.

\section{S. 1 Energy Use Study}

Continuous measurement w11l be made for a year or more of the fuel oll used, electrical energy generated, thermal energy utllized, excess heat discarded, and the incremental use of electr1cal and thermal energy by all major segments of the load.

Fuel oll consumption w111 be measured for all englnes and both bo1lers, and separately for each of two selected englnes to provide a bas fo for determining typlcal engine perforance.

Electrical energy w111 be masured at all mofor polnts of ut1l1zation including (a) the amount distributed to the site, (b) the amount used by each bullding, (c) that used by the commerclal area, (d) that used by the schools, (e) the amount used by plant aux1l1arles, and (f) that used by the central solld-waste collection system. The electrical energy generated by each of two of the englne-generators w111 be measured separately. The data collection system will also permlt determination of the energy demand integrated over time perlods of flve minutes or any multiple thereof up to dally and weekly patterns. Diverslty factors of energy use among the dwelling units in each apartment bullding can also be 25 determined. 
The thermal energy used in the absorption ch1llers, and in the primary hot water heat exchangers in the plant and that discharged through the water-to-alr coolers (dry coolers) and through the engine-o1l coolers w1ll be recorded at flve minute intervals and integrated by computer

5 programs. Simllarly the thermal energy used in each bullding for apace heating and cooling and for domest1c water heating w11 be recorded at Elve minute intervals and integrated.

\subsection{Performance of Major Plant Components}

The data collected on fuel use, electrical energy generation, thermal 10 energy produced, and thermal energy ut1lized w111 permit determinatlon of the thermal efficlency of the englne-generators, the heat recovery bo1lers, the absorption chillers, and the supplementary bollers. By analyols of these data at varlous load levels performance curves can be produced for all major types of mechanical equipment in the plant. Significant temper-

15 atures, pressures, speeds, and other operating parameters w11 be determined at the various load levels.

\subsection{Stab111ty of Electrical Service}

Recordings w1ll be made by the analog data system of transient conditions of voltage, frequency, power factor, and load divlsion durlag

20 sudden load changes on the system, during load-dumplag conditlons when overloads occur, and during the planned sequences of adding an eaglnegenerator to the distribution system or disconnecting one from service. These data will not be collected continuously, but on a planned besis when the phenomena permlt, or durlng short perlod of eargency whonever 25 these occur. 


\subsection{Rellabllity of Services}

Detalled records w111 be made of the durat1on and character1st1c parameters of intertuptions to the electrical service and heating and cooling services caused by overload or malfunction of equipment. The functioning of all of the alarms and protective devices on the englnech1llers, bollers, and ch1llers w11l be montrored. These operating data, together w1th documented maintenance and repa1r operat1ono, w11 constitute a record of rellabllity of the principal aechanical and electrical components of the plant.

\subsection{Environmental Cond1tions at the Total Energy Plant}

In addition to the alr pollution and nolse ourveys described earlier in th1s report, nolee and Fibration measurements w11 aloo be made of each englne-generator after Installation for compar1son with simllar dats taken dur1ng factory tests and as a bas for entanting approprlate overhaul perlods for the engines. Lubricating oll coateinat levels w111 also be monltored as a possible indicator of englne condition.

Ilumination levels, thermal environment, and vent1lation arouad major pleces of plant equipment and controls w11 be observed and compared with specificstion requirenents.

\subsection{Ownlng and Operating Costs}

A complete record of awning and operat1ng costs for the total energy plant w11l be kept including investment cost, flnencing costs and fees, fuel costs, costs for scheduled antenance and overhaul, and for breakdown malntenance, costs for repalr parts and laventory, plant operation and management, taxes, depreciation, Insurance, and water; and credits for energy supplied to other fac1l1t1es and for decreases in costs for other 
services such as solld-waste management. Record of maintenance, repalr, and overhaul costs w111 be kept for a perloal of three to five years to properly evaluate the effect of the minor and mafor overhaul of englnes on total costs.

The results from the Jersey'C1ty study are expected to constitute a good technical and economic base for evaluating the potential for wlder application of total energy plants. Th1s atudy and parallel warket studies should provide sufflcient data to consider whether total energy plants could be beneflclally comblned with waste treatment facllities or used 10 as satel11te systems interconnected w1th urban energy systems. 

NBS.114A (REV. 7.73)

U.S. DEPT. OF COMM.

BIBLIOGRAPHIC DATA SHEET

1. PUBB.IC ATION OR RIIPORT NO.

2. Ciov't Acression No.

NBS TR $-75-711$

4. TITLE AND SUBTITLE:

Site Analysis and Field Instrumentation for an Apartment Application of a Total Energy Plant

5. Publication Date

May 19, 1975

6. Performing Organization Code

8. Performing Organ. Report No.

John B. Coble and Paul R. Achenbach

7. AUTHOR(S)

ORGANIZATION NAMI: AND ADIDR I:SS

10. Project/Task/Work Unit No. 4628422

NATIONAL BUREAU OF STANDARDS

DEPARTMENT OF COMMERCE

WASHINGTON, D.C. 20234

11. Contract/Grant No.

12. Sponsoring Organization Name and Completc Address (Street, City, State, ZIP)

U. S. Department of Housing and Urban Development

4517 th Street, N.W.

Washington, D.C. 20410

13. Type of Report \& Period Covered

Fina?

14. Spunsoring Agency Code

15. SUPPI.EMENTARY NOTES

This NBS IR combines two talks given by J.B.Coble and

P.R.Achenbach at the 7th Intersociety Energy Conversion Engineering Conference at San Diego, California, September 25-29, 1972.

16. A BSTRACT (A 200-word or less tactual summary of most significant information. If document includes a significant bibliography or literglure suryey mention it here.)

Under sponsorship of the Department of Housing and Urban Development, the National

Bureau of Standards developed criteria in a feasibility study to select a site for, and to evaluate the requirements of a total energy system on one or more OPERATION BREAKTHROUGH housing sites. The total energy system produces its own electrical, heating and cooling energy services independent of the local utility system. Six OPERATION BREAKTHROUGH sites were selected for the feasibility study: Jersey City, N.J. Macon, Ga.; Memphis, Tenn.; Indianapolis, Ind.; St. Louis, Mo.; and Sacramento, Calif. Ranking parameters for final selection were: number of dwelling units, density of dwelling units, climatic factors, energy utilization, owning and operating costs, and developer's attitude.

The Jersey City site was chosen as the location for the installation, evaluation, and field study of the total energy system. The site covers six acres, has four apartment buildings containing 488 dwelling units, a 50,000-sq. ft commercial building, an elementary school, a swluming pool, and the total energy plant.

The buildings and the total energy plant are being extensively instrumented to provide data on fuel utilization, system efficiencies, electrical and thermal energy generation, energy utilized and rejected. The enviromental impact of the total energy plant with respect to noise, vibration, air pollution, and esthetics is under evaluation. The installed system will be compared with several types of conventional energy systems.

17. KEY WORDS (six to iwelve entries; alphabefical order; capitalize only the first lefler of the first key word unless a proper name; separafed by semicolons) Air conditioning; air pollution; central utility systems; data acquisition system; efficiencies; electrical power; energy conservation; energy costs; fuel ut1lization; heat recovery; total energy systems; utilities for housing; utility system performance.

18. AVAILABILITY [XQ9unlimited

For Official Distribution. Do Not Release to NTIS

Order From Sup. of Doc., U.S. Governmene Printing Office Washington, D.C. 20402, SD Cat. No. C13

[X] Order From National Technical Information Service (NTIS) Springfield, Virginia 22151

\begin{tabular}{|c|c|}
\hline $\begin{array}{l}\text { 19. SECURITY CI.ASS } \\
\text { (THIS REPURT) } \\
\text { (INCL ASSIFIED) }\end{array}$ & $\begin{array}{c}\text { 21. NO. OF PAGES } \\
63\end{array}$ \\
\hline $\begin{array}{l}\text { 20. SECURITY (IASS } \\
\text { (THIS PAGE) } \\
\text { UNC I.ASSIIIEI) }\end{array}$ & $\begin{array}{l}\text { 22. Price } \\
\$ 4.25\end{array}$ \\
\hline
\end{tabular}


- 


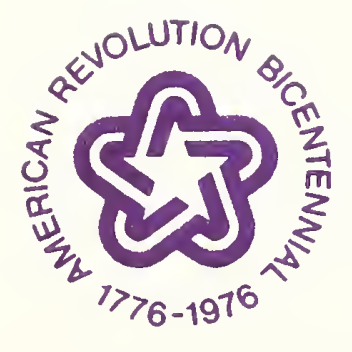

